\title{
Chancellor Angela Merkel: a Celtic satire
}

\section{Anthony Stephens}

She leads all Germany. Wagner's vision splendid trots through the gore of the party-room, choosing the slain like fruit for a glacé tart. 'No Bavarian quinces this time round! Imagine: poor, dear Chirac broke a filling on that sour Stoiber!' But as well she's Catherine the Great - and guess who's coming to Stralsund: yes! Bush no less! All the star-force boys togged-up as peasants, happily lining the empty streets, waving flags, folk-dance the Great Friend by. No girls in the act? But how would Bush notice, when next to him Angela outshines the rest of her sex? - whispers sweetly: 'My Potemkin, my pumpkin, my strudel!' into the President's ear... What a shame it's turned off.

Meanwhile Germany greys. Not even a Grand Coalition can get them breeding again, and always: more and more Turks. Angela has the Nation's top chemists all slaving on Project Late Afternoon, a Schwarzwälder Torte so aphrodisiac that even affluent singles will go it like rabbits, while unused condoms uncurl amid cake crumbs and spilled coffee: her legacy to the Nation. 'Shall I call it Donner und Blitz or Coup de foudre? Such a strain to be so European - and keep the place clean! And pensioners - more and more piggy-back on one worker! What's wrong with the joys of motherhood? It's subsidised! God knows: they've been told off to show me surrounded by kiddies: the Nation needs procreation - just nibble this cake!'

'Schröder left messes - him and his Russian gas! - he made too many of them Germans, just for filling the schools with offspring who can't learn grammar! And mess multiplies: the banks are all selling each other over the border; 
Volkswagen's gone to Brazil and Mercedes in Mysore's using child labour - more plum cake for Spiegel to scoff! And - all the time - the yeasty deficit rises; scandals, turncoats, critics sour the mix. The West's still cruel to the East, health's too dear, Brussels is brutal - really, I've so little time to bestride the world stage, waving my spear, like the Valkyrie I am - let alone ride! Such a shame Wagner left out the Grand Coalition. At least I'll be offstage before Götterdämmerung, calming my nerves - baking cakes!' 